\title{
Perceived Emotional Intelligence Assessment - The Portuguese Validation of Schutte's Emotional Intelligence Scale (SEIS-P)
}

\author{
Cibele Satuf ${ }^{1}$ \\ Federal University of Minas Gerais, Belo Horizonte-MG, Brasil \\ Samuel Monteiro \\ NECE - Research Center in Business Sciences, University of Beira Interior, Portugal \\ Graça Esgalhado, Henrique Pereira, Rosa Marina Afonso, Manuel Loureiro, Maria Miguel Barbosa \\ University of Beira Interior, Covilhã, Portugal
}

\section{ABSTRACT}

The aim of this study was to expand the (perceived) emotional intelligence scientific assessment domain and to validate the Schutte Emotional Intelligence Scale (SEIS) with Portuguese speaking adults. The research sample was composed of 2,380 subjects, all Portuguese speakers, with a mean age of 34.91 years. The factorial validity analysis produced four factors, similar to the international reference studies with this scale, which explained $45.56 \%$ of the total variance. In accordance with the theoretical and instrumental background, the four factors were named: Recognition of others' emotions; Recognition and communication of one's own emotions; Management of one's own emotions and Use of emotions. The adapted instrument presented valid psychometric characteristics for the assessment of perceived emotional intelligence, suggesting that the Portuguese version of the SEIS maintains the content validity and a regular structure, when compared to previously adapted and explored versions.

Keywords: emotional intelligence; Schutte; factor analysis; statistical validation; Portuguese speaker.

RESUMO - Avaliação da Inteligência Emocional Percebida - Validação Portuguesa da Escala de Inteligência Emocional de Schutte (EIES-P)

O objetivo deste estudo foi expandir o domínio de avaliação científica da inteligência emocional (percebida) e validar a Escala de Inteligência Emocional de Schutte (SEIS) para adultos falantes de língua portuguesa. A amostra pesquisada foi formada por 2.380 indivíduos, todos falantes de português, com idade média de 34,91 anos. A análise da validade fatorial mostrou quatro fatores, semelhante aos estudos internacionais de referência com essa escala, que explicaram $45,56 \%$ da variância total. Em consonância com os antecedentes teóricos e instrumentais, os quatro fatores foram denominados: Reconhecimento das emoções dos outros; Reconhecimento e comunicação de suas próprias emoções; Gerenciamento de suas próprias emoções e Uso de emoções. O instrumento adaptado demonstrou características psicométricas válidas para avaliação da inteligência emocional percebida, sugerindo que a versão em português da SEIS mantém a validade do conteúdo e uma estrutura regular, em comparação com versões previamente adaptadas e exploradas.

Palavras-chave: inteligência emocional; Schutte; análise fatorial; validação estatística; língua portuguesa.

RESUMEN - Evaluación de la Inteligencia Emocional Percibida - Versión Portuguesa de la Escala de Inteligencia Emocional de Schutte (EIES-P)

El objetivo de este artículo fue expandir el dominio de evaluación científica de la inteligencia emocional (percibida) y validar la Escala de Inteligencia Emocional de Schutte (SEIS) para adultos hablantes de lengua portuguesa. La muestra investigada fue formada por 2380 individuos con una edad media de 34.91 años. El análisis de la validez factorial presentó cuatro factores, equiparable a los estudios internacionales de referencia con esta escala, que resultó el $45.56 \%$ de la varianza total. En conformidad con los antecedentes teóricos e instrumentales, los cuatro factores fueron denominados: Percepción emocional de los demás; Reconocimiento y comunicación de sus propias emociones; Gestión de sus propias emociones; y Utilización de emociones. El instrumento adaptado mostró características psicométricas válidas para evaluar la inteligencia emocional percibida, sugiriendo que la versión en portugués de la SEIS mantiene la validez del contenido y una estructura regular, en comparación con versiones previamente adaptadas y exploradas.

Palabras clave: inteligencia emocional; Schutte; análisis factorial; validación estadística; lengua portuguesa.

The interest in Emotional Intelligence (EI) has not been accompanied by agreement as to how it should be defined, operationalized or even assessed. Therefore, several axes of theorization have emerged (Omar, Salessi, Urteaga, Diego, \& Vaamonde, 2014), organised in skills models (setting out from a conceptualization giving a 
cognitive character to EI) and in mixed models (including non-intellective concepts, involving and combining a great variety of components besides skills) (Fragoso-Luzuriaga, 2015; Regner, 2008; Woyciekoski \& Hutz, 2009). Based on different theoretical approaches, multiple methodologies and instruments to assess EI have been developed (Rego \& Fernandes, 2005; Woyciekoski \& Hutz, 2009).

The term EI was introduced in the academic and scientific sphere by Salovey and Mayer (1990). The construct was approached according to the skills involved, with the authors recommending a model that included representation of three major competences: 1. appraisal and expression of one's own emotions and those of others; 2. regulation and control of emotions in oneself and others; and 3. the use of emotions to help solve everyday problems. Their studies were structured towards analysing how people examine and communicate their emotions, and how they use those emotions to solve problems. Subsequently, a revised definition proposed that EI involved the skill of perceiving, assessing and expressing emotions precisely; the use of emotions to facilitate thinking; analysis and understanding of emotions and reflexive regulation of emotions (Mayer, Caruso, \& Salovey, 2000a). Also for these authors, EI is considered a cognitive skill (Stys \& Brown, 2004).

The second theoretical group, named Mixed models, include non-intellective concepts, involving a large variety of components besides skills (Petrides \& Furnham, 2000; Queroz \& Neri, 2005; Schutte et al., 1998). According to Fragoso-Luzuriaga (2015), Regner (2008) and Woyciekoski and Hutz (2009) the conceptualizations of EI most prominent in mixed models are those of Reuven Bar-on and Goleman.

Bar-On (2006) considers emotional intelligence as a mixed intelligence, formed of cognitive skills and aspects of personality. EI can be described as a multifactor concept formed of inter-related and facilitating emotional and social competences that influence the individual's skill in recognizing, understanding and managing their emotions, relating to others, adapting and solving problems of a personal and interpersonal nature, as well as coping assertively with challenges and pressure experienced in daily life. This proposes the idea that the set of competences and facilitators has an impact on intelligent behaviour. For the author, models of human behaviour are influenced, to a certain extent, by bio-psycho-social factors, including cognitive intelligence, personality, motivation and environmental influences.

Another mixed approach is the one proposed by Daniel Goleman (1995), who carried out his studies mainly according to distinctive generic competences in the area of organisations (Rodrigues, Rebelo, \& Coelho, 2011; Trujillo Flores \& Rivas Tovar, 2005). In 1995, the author expanded the EI construct to include a number of social and communication variables related to understanding and expressing emotions. Later Goleman (1998) emphasized the role of relationships and daily experiences and their influence on success in solving everyday problems. The theoretical model of EI included five basic components: self-awareness, motivation, self-regulation, empathy, and social skills. Emotional Intelligence "refers to the capacity for recognizing our own feelings and those of others, for motivating ourselves, and for managing emotions well in ourselves and in our relationships" (1998, p. 317). An reformulated proposal was developed by Boyatzis, Goleman and Rhee (2000), which consisted in the theoretical and empirical cluster of twenty emotional competences forming four components: self-awareness, self-management, social awareness and the ability to manage relationships/ social competence.

In a broader conception, Petrides and Furnham (2000) indicated that emotional intelligence can be approached as a trait and information processing. The first approach, structured through personality and accessed through self-response inventories (like those of Bar-On and Schutte), focuses on the transversal consistencies of behaviour, manifest in behaviours and traits such as assertiveness and optimism. The information processing approach is concerned with skills, such as that of identifying and expressing emotions, and can be accessed through performance measures (i.e. MEIS by Mayer, Caruso and Salovey).

\section{Assessment of Emotional Intelligence}

Over time, multiple methodologies and instruments have been developed to evaluate Emotional Intelligence, whose evolution was based on existing theoretical approaches (Faria et al., 2006; Fragoso-Luzuriaga, 2015; Trujillo Flores \& Rivas Tovar, 2005). In order to assess the elements that define EI, authors who defend skills models recommend the use of performance instruments (Mayer, Roberts, \& Barsade, 2008; Regner, 2008; Salovey, Mayer, Goldman, Turvey, \& Palfai, 1995; Trujillo Flores \& Rivas Tovar, 2005; Woyciekoski \& Hutz, 2009). These tests present specific problems and tasks for which there is only one correct answer that can be assessed according to pre-determined objective criteria (Caruso, Mayer, \& Salovey, 2002; Mayer et al., 2000a; Mayer, Salovey, \& Caruso, 2004; Woyciekoski \& Hutz, 2009). This type of instrument gives direct access to the subject's level of performance in the task, as well as objective indicators grounded on personal capacity and performance, directly assessing EI (Caruso et al., 2002; Costa \& Faria, 2014)

The first instrument to use performance as the basis for measuring emotional intelligence was the Multifactor Emotional Intelligence Scale (MEIS), developed by Mayer, Salovey, and Caruso in 1997 (Bueno \& Primi, 2003). This scale aims to determine individual performance in tasks of emotional situations and evaluates EI as information processing, being divided in four components: perception of emotions, use of emotions to facilitate thinking, understanding emotions and managing 
emotions (Mayer, Caruso, \& Salovey, 2000b). Later, Mayer, Salovey, Caruso and Sitarenios (2003) launched a version aiming to improve the previous measures, named the Mayer-Salovey-Caruso Emotional Intelligence Test, Version 2.0 (MSCEIT, V2.0), which maintained the four components of assessment in its structure MSCEIT, launched in 2000, with 141 items.

The development of measures to assess EI based on the theoretical assumptions of mixed models usually culminates in self-report instruments (Caruso et al., 2002; Kun, Balazs, Kapitany, Urban, \& Demetrovics, 2010; Mayer et al., 2008; Regner, 2008; Trujillo Flores \& Rivas Tovar, 2005; Woyciekoski \& Hutz, 2009). However, there are tools which, although applied in the self-report form, are based theoretically on the assumptions of the skills models (Fernández-Berrocal \& Extremera, 2006; García-Coll, Graupera-Sanz, Ruiz-Pérez, \& PalomoNieto, 2013; Rodrigues et al., 2011). Self-report instruments provide important indicators because they operate through questionnaires where the person reports the perception of their EI (Woyciekoski \& Hutz, 2009). According to Fernández-Berrocal and Extremera (2006), this is the most commonly used type of measure in this field of study. Currently, the most renowned self-report instruments and those most used internationally are the TMMS (Trait Meta-Mood Scale), the EQ-i (Emotional Quotient Inventory) and the AES (Assessing Emotions Scale) (Ciarrochi, Chan, \& Caputi, 2000; Dawda \& Hart, 2000; Woyciekoski \& Hutz, 2009).

The TMMS was developed by Salovey et al. (1995), and its construction was based on the theoretical model of skills by Salovey and Mayer (1990). This instrument assesses the inter-personal aspects of EI (Fernández-Berrocal \& Extremera, 2006), being composed of forty-eight items, answered on a five-point Likert scale (De Haro \& Castejón, 2014; Trujillo Flores \& Rivas Tovar, 2005). It is formed of three sub-factors: attention to one's own emotions, emotional clarity and emotional repair (Extremera, Fernández-Berrocal, Ruiz-Aranda, \& Cabello, 2006). According to Fernández-Berrocal and Extremera (2006), this instrument is easy to apply, score and interpret, with a response time of approximately ten minutes.

The EQ-i instrument, developed by Bar-On in 1997, was the first measure of its kind to be published by a psychological test publisher and the most widely used measure of emotional-social intelligence. The instrument has been translated into more than twenty-two languages and normative data has been collected in more than fifteen countries (Bar-on, 2000). The inventory presents 133 items and is based on a theoretical model in which effective emotional and social functioning should eventually lead to a feeling of psychological well-being. The instrument is formed of five scales that comprise 15 subscale scores: 1. Intrapersonal, comprising SelfRegard, Emotional Self- Awareness, Assertiveness, Independence, and Self-Actualization. 2. Interpersonal, comprising Empathy, Social Responsibility, and Interpersonal Relationship. 3. Stress Management, which includes Stress Tolerance and Impulse Control. 4. Adaptability, which consists of Reality-Testing, Flexibility, and Problem-Solving. 5. General Mood, comprising Optimism and Happiness (Bar-on, 2000; Bar-On, 2006). A reviewed version of the scale, EQ-i 2.0, was recently published, keeping the same factor structure, despite some items having been added or reorganised (Bar-On, 2012).

Also widely used is the Assessing Emotions Scale (AES) developed by Schutte et al. (1998). This instrument can also be called the Self-Report Emotional Intelligence Test (SREIT) or Schutte Emotional Intelligence Scale (SEIS) (Schutte, Malouff, \& Bhullar, 2009). AES, whose development was based on the theoretical model by Salovey and Mayer (1990), aims to provide an index of perception of competence in relation to the assessment and expression of emotions (one's own and of others), regulation and control of emotions (in oneself and others) and the use of emotions in problemsolving (Schutte et al., 1998). This instrument is formed of 33 items and uses a Likert response scale (Schutte et al., 2009, 1998), taking an estimated average of five minutes to complete (Schutte et al., 2009). The instrument's authors claim it presents a one-dimensional structure to assess the general factor of perceived EI, recommending calculation of the total score of the instrument. The scores obtained can range between 33 to 165, with higher scores tend to indicate higher perception of EI (Brown \& Schutte, 2006; Schutte et al., 2009, 2001).

The scale was subject of studies involving translations and cultural adaptations, such as versions in Turkish (Cakan \& Altun, 2005); Swedish (Sjoberg, 2001; Sjöberg \& Engelberg, 2004); Chinese (Chan, 2003, 2004); Polish (Ogińska-Bulik, 2005); Hebrew (Carmeli, 2003; Carmeli \& Josman, 2006); Spanish (García-Coll et al., 2013); Transcultural (Argentinian, Mexican and Brazilian) (Omar et al., 2014), among others.

Unlike the two instruments to measure EI mentioned above, which underwent revisions culminating in new versions, the discussions around the Assessing Emotions Scale involve the exploration or confirmation of its factor structure. Initially, the solution proposed by the authors indicated a one-factor structure, formed of the 33 items forming the scale (Schutte et al., 1998). Later, exploratory and confirmatory studies were carried out. Among these, the most disseminated are those by Petrides and Furnham (2000), Ciarrochi, Chan, and Bajgar (2001) and Saklofske, Ausin, and Minski (2003), which indicated a 4-factor structure, keeping the 33 items of the original version, although the organisation of the items did not remain the same (Schutte et al., 2009). The first found that the 33 items, grouped in four factors, named by them as optimism/mood regulation, assessment of emotions, social skills and use of emotions, 
explained $40.4 \%$ of the total variance, justifying the adoption of this scale structure (Petrides \& Furnham, 2000).

Based on the scale validation studies by Petrides and Furnham (2000), Saklofske et al. (2003) also found a structure formed of the same four factors, maintaining the previously described nomenclature. The four-factor structure was also confirmed by Keele and Bell (2008); García-Coll et al. (2013); Chan (2003) and Saklofske, Austin, Mastoras, Beaton, and Osborne (2012). Other studies indicated a structure formed of two factors (Omar et al., 2014); three factors (Austin, Saklofske, Huang, \& McKenney, 2004; Kun et al., 2010); or six factors (Gignac, Palmer, Manocha, \& Stough, 2005; Jonker \& Vosloo, 2008; Lane et al., 2009).

Toledo Junior, Duca and Coury (2018) conducted validation studies of AES in the Portuguese language. However, they considered only the verification of the internal validity and consistency of the overall instrument, thus not including verification of the structure of items and dimensions of the scale. On the other hand, the studies of Omar et al. (2014) were limited to younger participants. Although many measures of emotional intelligence are available, validated instruments for Portuguese speakers are scarcely offered. Therefore, we seek to contribute to specific literature, providing elements that subsidize the use of this instrument to measure emotional intelligence. Although the scale is generally considered as multifactorial, it is noted an instability regarding the organization of these factors, as previously pointed out. Thus, several authors (Keele \& Bell, 2008; Ng, Chuang Wang, Kim, \& Bodenhorn, 2010; Saklofske et al., 2003) suggest research to confirm its structure. Thus, this research aims to explore the factor structure of the Assessing Emotions Scale with a sample formed of Portuguese-speaking adults. We aim at performing the analysis of the psychometric properties of the scale, as well as its validation for this population.

\section{Method}

\section{Procedures}

This research is of a descriptive, quantitative and transversal nature. A request for participation was sent via the internet between the first and last trimesters of 2015, using lists of e-mail addresses, contact with firms and social networks. This collection method has become common in the field of Psychology and Social Sciences due to the low implementation costs, together with the autonomy and flexibility given to respondents (Vaus, 2014), and studies indicate that it maintains the statistical equivalence of more traditional collection methods (Ramsey, Thompson, McKenzie, \& Rosenbaum, 2016).
The form used contained information about the study objectives and the research team, as well as the terms of informed consent. Participants were assured of the confidentiality and anonymity of their answers. The study also followed the ethical principles and guidelines of research involving human beings proposed by the American Psychological Association (APA), regarding to confidentiality and informed consent. Respondent's participation was voluntary and did not result in any damaging consequences. In addition, the anonymity of the participants was assured, and data were analysed in a way that didn't allow their individual identification. The research project was assessed and approved by the Ethics Commission of the University of Beira Interior.

\section{Participants}

The sample was formed of 2380 subjects, all Portuguese speakers ${ }^{2}$, with an average age of 34.91 years $(S D=13.77)$. Regarding gender, the sample was relatively well distributed (53.4\% male and $46.5 \%$ female). The predominant marital status was married (39\%), the majority had at least higher education (85.3\%), with $33.8 \%$ being graduates, $37.9 \%$ masters and $13.6 \%$ having a Ph.D. or post-Ph.D. The majority lived in urban areas (88.7\%), lived in their own home (68.9\%) and were employed (59.7\%), with $45.9 \%$ being self-employed and $14.3 \%$ employees. As for the type of institution, 50.6\% worked in private companies and $45.4 \%$ in State companies.

\section{Measuring instruments}

Socio-demographic questionnaire. The sociodemographic questionnaire aimed to characterize the sample and was formed of items such as gender, age, place and type of residence, education, professional situation and type of institution, in the case of workers.

Emotional Intelligence Scale. The Assessing Emotions Scale was developed aiming to access the perception of characteristics, or traits of emotional intelligence (Schutte et al., 2009), based on the theoretical model by Salovey and Mayer (1990) in which the construct was composed of analysis and expression of emotions; regulation of emotions; and use of emotions. The authors elaborated a series of 62 items using a Likert response scale that varied from 1 (strongly disagree) to 5 (strongly agree).In a first analysis, the authors performed a factor analysis of principal components, with orthogonal rotation, whose scree plot generated a structure with four factors, the first formed of 33 items and an eigenvalue of 10.79 . The authors found that all these 33 items corresponded to the theoretical structure used, with 13 of them related to assessment and expression of emotions, 10 items related to regulation of emotions and 10

2 This research was addressed to participants from Portuguese Speaking Countries Community (CPLP), mainly Portuguese and Brazilian, considering the Portuguese language as a unique language. Although the language has variations in these two countries, these do not compromise the full understanding of the instrument. 
corresponding to the use of emotions. The other items had no theoretical relation with the model adopted and were eliminated. Therefore, the final version of the scale was formed of 33 items oriented in a one-factor structure, with internal consistency confirmed using the Cronbach alpha, which was .90 in the first study and .78 in the retest (Schutte et al., 1998).

Following the guidelines for translation and crosscultural adaptation (e.g., Beaton, Bombardier, Guillemin, \& Ferraz, 2000; Brislin, 1986; Gjersing, Caplehorn, \& Clausen, 2010) the original English version was independently translated into Portuguese (cf. Vicente, 2014). The two versions were discussed and compared. Thus, the Portuguese version was back translated and compared to the original scale in English. The comparison showed that there were no relevant differences in the content of the two versions of the scale.

Positive and Negative Affect Schedule PANAS. The subjective well-being (BES) refers to the description of the level of well-being experienced by the person, according to his/her subjective evaluation. This evaluation, which may be positive or negative, includes judgments about life satisfaction, commitment and affective relationships, as well as the evaluation of several domains, such as work and relationships (Satuf et al., 2018). People with higher levels of emotional intelligence tend to have higher levels of subjective well-being (Bar-On, 2005; Schutte, Malouff, Simunek, McKenley, \& Hollander, 2002).

BES was accessed through the brief version of the positive and negative affect scale (PANAS-VRP), validated for the Portuguese population (Galinha, Pereira, \& Esteves, 2014). The scale has 10 items, 5 for positive affect assessment and 5 for negative affect assessment. The possible answers utilized a Likert scale, ranging from $1=$ nothing or very little to $5=$ extremely. In the scale's validation studies, the Cronbach's $\alpha$ values were found to range from 0.86 to 0.89 for positive affect and negative affect, respectively (Galinha et al., 2014).

\section{Statistical Analysis of the Data}

Data analysis was performed using the Statistical Package for Social Sciences (SPSS), version 22. The factor structure of the Assessing Emotions Scale was confirmed through Exploratory Factor Analysis (EFA), using the principal component extraction method, and Varimax rotation, an orthogonal method that seeks to maximize the spread of loads among factors, facilitating their interpretation (Field, 2013). To define the number of factors to be extracted, Parallel Analysis (PA) was used, consisting of comparing the eigenvalues extracted from the researcher's database with those extracted from a random correlation matrix using the same size of sample and number of variables. The number of factors to retain will be indicated by the eigenvalues of the researcher's database that are greater than those of the random correlation matrix (Patil, Singh, Mishra, \& Todd Donavan, 2008). The other decision criteria observed during the EFA process were the retention of items with a factor loading of at least 0.4 , as recommended by Ford, MacCallumand and Tait (1986) and Stevens (2009); the non-existence of items with cross-loading; a percentage of variance explained of at least $40 \%$; and retention of factors with at least three items. In order to test the psychometric properties of the scale, in addition to its factorial exploration, Pearson correlation analyzes are performed, in order to analyze the association between items and scale factors. The discriminant validity of the scale is verified through the association between emotional intelligence and subjective well-being, since this construct is theoretically related to EI.

\section{Results}

Initially, the Kaiser-Meyer-Olkin (KMO) values were calculated, with the value found, .910 , being considered very good (Leech, Barrett, \& Morgan, 2015), and the Bartlett values $\left(\chi^{2}=14804.33, p<.001\right)$, and the antiimage correlation matrix was checked, obtaining values between .853 and .949 . The values found allowed exploratory factor analysis to continue, carried out through the principal components method, with the extraction of 4 factors (as indicated by the PA) and Varimax rotation.

The next step was exclusion of the items with a factor loading under .40 (Ford et al., 1986; Stevens, 2009), and then the items in cross-loading were excluded. The final version of the scale was formed of 23 items, distributed in four factors, the first with 6 items, the second with 7 items, and the third and fourth factors with 5 items in each, as indicated in Table 1.

The items were distributed in a structure formed of four factors: factor 1, named "Recognition of others' emotions"; factor 2, called "Recognition and communication of one's own emotions"; factor 3 called "Management of one's own emotions"; and factor 4 called "Use of emotions". This distribution reflects the theoretical model proposed by Salovey and Mayer (1990) in which emotional intelligence includes assessment of one's own emotions and those of others, expression of emotions, regulation of emotions in oneself and in others and the use of emotions in problem-solving (Schutte et al., 2009). This was followed by confirmation of the Total Explained Variance and the Cronbach alpha values for each factor (cf. Table 2).

Evaluating the Factorial Structure Reliability with the George and Mallery (2003) guidelines we may see that the second, third and fourth factors presents acceptable indicators, but the first one presents the lowest value, that is between .51 and .60 , and could be considered "poor" or even unacceptable in more demanding standards where, in general, an instrument or test is classified as having appropriate reliability when alpha is, at least, 
70 (Nunnaly, 1978). In fact, the value of Cronbach's alpha is influenced both by the value of the correlations of the items, and by the number of items evaluated
(Cortina, 1993), and this specific dimension results must be considered with careful and taking into consideration in future validation studies of this scale version.

Table 1

Item Distribution by Factors

\begin{tabular}{|c|c|c|c|c|}
\hline & 1 & 2 & 3 & 4 \\
\hline Item 29 & .759 & .019 & .017 & .123 \\
\hline Item 32 & .726 & .063 & .064 & .155 \\
\hline Item 25 & .634 & .340 & .020 & .114 \\
\hline Item 26 & .570 & .117 & .072 & .262 \\
\hline Item 33 & -.491 & -.023 & -.121 & .105 \\
\hline Item 30 & .486 & .272 & .326 & .072 \\
\hline Item 1 & .264 & .665 & -.008 & .113 \\
\hline Item 15 & .063 & .657 & .166 & .053 \\
\hline Item 11 & .056 & .612 & .095 & .122 \\
\hline Item 14 & -.075 & .576 & .360 & .025 \\
\hline Item 12 & .199 & .566 & .283 & .283 \\
\hline Item 13 & .101 & .523 & .208 & .110 \\
\hline Item 19 & .298 & .432 & .064 & .273 \\
\hline Item 3 & .019 & .141 & .718 & .114 \\
\hline Item 10 & .021 & .161 & .679 & .138 \\
\hline Item 31 & .375 & .188 & .561 & .167 \\
\hline Item 23 & .319 & .146 & .557 & .231 \\
\hline Item 2 & .071 & .332 & .469 & .241 \\
\hline Item 7 & -.042 & .104 & .026 & .771 \\
\hline Item 20 & .178 & .141 & .312 & .644 \\
\hline Item 27 & .396 & .114 & .118 & .546 \\
\hline Item 17 & .161 & .155 & .319 & .534 \\
\hline Item 6 & .078 & .257 & .221 & .420 \\
\hline
\end{tabular}

Table 2

Explained Variance and Cronbach alphas of the Factors

\begin{tabular}{lccc}
\hline \multicolumn{1}{c}{ Factor } & $\begin{array}{c}\text { Total } \\
\text { Explained } \\
\text { Variance }\end{array}$ & $\begin{array}{c}\text { Total Explained } \\
\text { Variance (Comulative) }\end{array}$ & $\begin{array}{c}\text { Cronbach's } \\
\text { alpha }\end{array}$ \\
\hline 1. Recognition of others' emotions & $27.86 \%$ & $27.86 \%$ & .52 \\
2. Recognition and communication of one's own emotions & $7.85 \%$ & $35.71 \%$ & .76 \\
3. Management of one's own emotions & $5.51 \%$ & $41.23 \%$ & .73 \\
4. Use of emotions & $4.43 \%$ & $45.66 \%$ & .69 \\
\hline
\end{tabular}

Aiming to confirm the scale structure, the convergent-validity of the items was examined, which allows identification of the correlations between items and factors, with the correlations of the items being expected to be stronger with the factor they belong to (cf. Table 3).

Finally, the discriminant validity of the scale was measured using Pearson's correlation analyzes between the dimensions of the emotional intelligence scale and the subjective well-being scale. The results (Table 4) show a high association between AES dimensions and positive and negative affects, as previously reported by (Omar et al., 2014). The associations varied between $r=-.20, p<.01$ and $r=.55, p<.01$. 
Table 3

Convergent Validity of the Items of the Assessing Emotions Scale

\begin{tabular}{|c|c|c|c|c|}
\hline & $\begin{array}{c}\text { Factor } 1 \\
\text { Recognition of } \\
\text { others' emotions }\end{array}$ & $\begin{array}{c}\text { Factor } 2 \\
\text { Recognition and } \\
\text { communication of } \\
\text { one's own emotions }\end{array}$ & $\begin{array}{c}\text { Factor } 3 \\
\text { Management of } \\
\text { one's own emotions }\end{array}$ & $\begin{array}{c}\text { Fator } 4 \\
\text { Use of emotions }\end{array}$ \\
\hline Item 29 & $.720^{* *}$ & $.224^{* *}$ & $.232^{* *}$ & $.278^{* *}$ \\
\hline Item 32 & $.714^{* *}$ & $.277^{* *}$ & $.276^{* *}$ & $.310^{* *}$ \\
\hline Item 25 & $.636^{* *}$ & $.406^{* *}$ & $.314^{* *}$ & $.338^{* *}$ \\
\hline Item 26 & $.666^{* *}$ & $.292^{* *}$ & $.301^{* *}$ & $.348^{* *}$ \\
\hline Item 30 & $.589^{* *}$ & $.413^{* *}$ & $.421^{* *}$ & $.360^{* *}$ \\
\hline Item 33 & .030 & $-.148^{* *}$ & $-.155^{* *}$ & $-.138^{* *}$ \\
\hline Item 1 & $.221^{* *}$ & $.637^{* *}$ & $.374^{* *}$ & $.287^{* *}$ \\
\hline Item 15 & $.368^{* *}$ & $.652^{* *}$ & $.336^{* *}$ & $.320^{* *}$ \\
\hline Item 11 & $.238^{* *}$ & $.635^{* *}$ & $.307^{* *}$ & $.276^{* *}$ \\
\hline Item 14 & $.151^{* *}$ & $.623^{* *}$ & $.378^{* *}$ & $.272^{* *}$ \\
\hline Item 12 & $.346^{* *}$ & $.714^{* *}$ & $.514^{* *}$ & $.446^{* *}$ \\
\hline Item 13 & $.232^{* *}$ & $.638^{* *}$ & $.334^{* *}$ & $.297^{* *}$ \\
\hline Item 19 & $.321^{* *}$ & $.568^{* *}$ & $.340^{* *}$ & $.370^{* *}$ \\
\hline Item 3 & $.196^{* *}$ & $.349^{* *}$ & $.688^{* *}$ & $.344^{* *}$ \\
\hline Item 10 & $.208^{* *}$ & $.360^{* *}$ & $.656^{* *}$ & $.357^{* *}$ \\
\hline Item 31 & $.403^{* *}$ & $.424^{* *}$ & $.693^{* *}$ & $.423^{* *}$ \\
\hline Item 23 & $.345^{* *}$ & $.404^{* *}$ & $.720^{* *}$ & $.426^{* *}$ \\
\hline Item 2 & $.222^{* *}$ & $.444^{* *}$ & $.709^{* *}$ & $.402^{* *}$ \\
\hline Item 7 & $.185^{* *}$ & $.249^{* *}$ & $.275^{* *}$ & $.697^{* *}$ \\
\hline Item 20 & $.337^{* *}$ & $.399^{* *}$ & $.467^{* *}$ & $.740^{* *}$ \\
\hline Item 27 & $.433^{* *}$ & $.349^{* *}$ & $.383^{* *}$ & $.647^{* *}$ \\
\hline Item 17 & $.304^{* *}$ & $.391^{* *}$ & $.437^{* *}$ & $.683^{* *}$ \\
\hline Item 6 & $.231^{* *}$ & $.334^{* *}$ & $.366^{* *}$ & $.591^{* *}$ \\
\hline
\end{tabular}

** $p<.01$

Table 4

Pearson's Correlation between Assessing Emotions Scale and PANAS

$\begin{array}{lllll}1 & 2 & 3 & 4 & 5\end{array}$

1. Recognition and communication of one's own emotions

2. Management of one's own emotions

$.60^{* *}$

3. Recognition of others' emotions

4. Use of emotions

5. Positive affect

$.61 \quad .70^{* *}$

6. Negative affect

$.53^{* *} \quad .65^{* *} \quad .59^{* *}$

$.39^{* *} \quad .55^{* *} \quad .48^{* *}$

${ }^{* *} p<.01$

\begin{tabular}{lllll}
$-.24^{* *}$ & $-.31^{* *}$ & $-.26^{* *}$ & $-.20^{* *}$ & $-0.24^{* *}$ \\
\hline
\end{tabular}

\section{Discussion}

The exploratory factor analysis performed on the Portuguese version of the Assessing Emotions Scale identified a structure formed of four factors, agreeing with versions explored previously (Chan, 2003; Chapman \& Hayslip, Jr., 2005; Ciarrochi et al., 2001; Fukuda et al., 2011; García-Coll et al., 2013; Petrides \& Furnham, 2000; Saklofske et al., 2003). In these versions, similarities are seen in the naming of the factors: Optimism/
Regulation of mood (also called management of one's own emotions); Assessment (or perception) of emotions; Social skills (or management of others' emotions); Use of emotions (Chapman \& Hayslip, Jr., 2005; Ciarrochi et al., 2001; Fukuda et al., 2011; García-Coll et al., 2013; Petrides \& Furnham, 2000; Saklofske et al., 2003); and Management of one's own emotions; Management of others' emotions or Social skills; Empathy; and Use of emotions (Chan, 2003). Despite slight differences in naming the factors, the orientation in relation to the 
concepts used is seen to remain. The nomenclature adopted in the present study is similar to that adopted by Ciarrochi et al. (2001).

However, the number of items and their distribution among the factors were not stable between these versions. This divergence may be related to how the items are presented and interpreted. It can be seen that some of them can refer to more than one of the components of EI, as is the case of item 32: "I can say how people feel, listening to the tone of their voice;" In the version validated by Petrides and Furnham (2000), this item was directed to the dimension called "mood regulation" (denominated by us as management of one's own emotions), whereas in the version validated here this item was allocated in dimension "Recognition of others' emotions". A close proximity between these two aspects is considered, which could be interpreted both as an ability to recognize what the other feels, and the ability to evaluate the presence of an emotion.

The factor solution found was demonstrated to be suitable in the KMO indices with suitable convergent-divergent validity, with the items correlating more strongly and significantly with the factors they belong to, except for item 33. The Cronbach alpha values obtained were also generally satisfactory. The factor of Recognition of others' emotions had a low alpha, similarly to other versions (Qualter, Ireland, \& Gardner, 2010). Although the literature recognizes this value of Cronbach's alpha as unacceptable (Maroco \& GarciaMarques, 2006), we advocate maintaining the structure of the scale, since these dimensions are closer to the theory associated with the evaluation of emotional intelligence. It is important to highlight that various investigations found low Cronbach alpha values in one of the dimension, which seems to be a common problem with this scale (Jonker \& Vosloo, 2008; Kun et al., 2010; Petrides \& Furnham, 2000). This suggests the need to repeat the analysis with several samples, since, even though it is extremely important, Cronbach's alpha has some limitations (Maroco \& Garcia-Marques, 2006). In addition, it is emphasized that the scale may contain items that are situated at apparently fluid boundaries between some of its dimensions. This reinforces the need for further evaluation.

Finally, discriminant validation of the scale, verified through the association between emotional intelligence and well-being, reinforced that subjects with higher levels of emotional intelligence tended to have an ability to maintain more frequent positive states. This suggests that people who recognize the emotions of others as well as those who recognize and manage their own emotions indicate a higher presence of subjective well-being (Omar et al., 2014).

This research fulfilled the objective proposed. It contributes to the Portuguese validation of an instrument widely used for the measurement of emotional intelligence. With this, it will allow the dissemination of a tool of analysis of a construct of salient importance, not only in the field of Psychology. However, like every investigation, it carries some limitations. The first one refers to the medium used in data collection, based on the self-report model. This may contribute to the bias of the results due to uncontrolled elements, such as social desirability. Moreover, it is a non-probabilistic sample, which makes it impossible to generalize the results found. However, from the results obtained, it is relevant to carry out future research in order to confirm the factor solution found here. An instrument validation is an ongoing process. So, more robust analyzes should be conducted in order to validate the factorial structure of the scale, using and comparing different kind of estimation methods and estimators, aiming to confirm the distribution of its items, as well as its reliability as a Perceived Emotional Intelligence measurement instrument.

\section{Acknowledgments}

Financial support and sponsorship: This research was supported by National Funds through "FCT Fundação para a Ciência e a Tecnologia" within the project UID / GES / 04630/2013.

\section{References}

Austin, E. J., Saklofske, D. H., Huang, S. H. S., \& McKenney, D. (2004). Measurement of trait emotional intelligence: Testing and crossvalidating a modified version of Schutte et al.'s (1998) measure. Personality and Individual Differences, 36(3), 555-562. doi: 10.1016/ S0191-8869(03)00114-4

Bar-on, R. (2000). Emotional and social intelligence: Insights from the Emotional Quotient Inventory (EQ-i). In R. Bar-On \& J. D. A. Parker (Eds.), The Handbook of Emotional Intelligence. Theory, development, assessment and application at home, school, and in the workplace (pp. 363-388). San Francisco, CA: Jossey-Bass.

Bar-On, R. (2006). The Bar-On model of emotional-social intelligence (ESI). Psicothema, 18(supl.), 13-25.

Bar-On, R. (2005). The impact of emotional intelligence on health and wellbeing. Perspectives in Education, 23(41-62). doi: 10.5772/57353

Bar-On, R. (2012). The Impact of Emotional Intelligence on Subjective Well-Being. In A. Di Fabio (Ed.), Emotional Intelligence - New Perspectives and Applications (pp. 29-50). InTech. doi: 10.5772/32468 
Beaton, D. E., Bombardier, C., Guillemin, F., \& Ferraz, M. B. (2000). Guidelines for the Process of Cross-Cultural Adaptation of SelfReport Measures. Spine, 25(24), 3186-3191. doi: 10.1111/cch.12124

Boyatzis, R. E., Goleman, D., \& Rhee, K. S. (2000). Clustering competence in Emotional Intelligence: insights from the Emotional COmpetence Inventory. In R. Bar-On \& J. D. A. Parker (Eds.), The Handbook of Emotional Intelligence. Theory, development, assessment and application at home, school, and in the workplace (1st ed., pp. 343-362). San Francisco, CA: Jossey Bass.

Brislin, R. W. (1986). The wording and translation of research instruments. In W. J. Lonner \& J. W. Berry (Eds.), Cross-cultural research and methodology series, Vol. 8. Field methods in cross-cultural research (pp. 137-164). Thousand Oaks, CA: Sage Publications, Inc.

Brown, R. F., \& Schutte, N. S. (2006). Direct and indirect relationships between emotional intelligence and subjective fatigue in university students. Journal of Psychosomatic Research, 60(6), 585-593. doi: 10.1016/j.jpsychores.2006.05.001

Bueno, J. M. H., \& Primi, R. (2003). Inteligência emocional: Um estudo de validade sobre a capacidade de perceber emoções. Psicologia: Reflexão e Crítica, 16(2), 279-291. doi: 10.1590/S0102-79722003000200008

Cakan, M., \& Altun, S. A. (2005). Adaptation of an emotional intelligence scale for. International Journal of Education, 6(3), 367-372.

Carmeli, A. (2003). The relationship between emotional intelligence and work attitudes, behavior and outcomes. Journal of Managerial Psychology, 18(8), 788-813. doi: 10.1108/02683940310511881

Carmeli, A., \& Josman, Z. E. (2006). The relationship among emotional intelligence, task performance, and the relationship among emotional intelligence, task performance, and organizational citizenship behaviors. Human Performance, 19(4), 403-419. doi: 10.1207/ s15327043hup1904

Caruso, D. R., Mayer, J. D., \& Salovey, P. (2002). Relation of an Ability Measure of Emotional Intelligence to Personality.Journal of Personality Assessment, 79(2), 306-320. doi: 10.1207/S15327752JPA7902_12

Chan, D. W. (2003). Dimensions of Emotional Intelligence and their relationships with social coping among gifted adolescents in Hong Kong. Journal of Youth and Adolescence, 32(6), 409-418. doi: 0047-2891/03/1200-0409/0

Chan, D. W. (2004). Perceived emotional intelligence and self-efficacy among Chinese secondary school teachers in Hong Kong. Personality and Individual Differences, 36(8), 1781-1795. doi: 10.1016/j.paid.2003.07.007

Chapman, B. P., \& Hayslip, Jr., B. (2005). Incremental Validity of a Measure of Emotional Intelligence. Journal of Personality Assessment, 85(2), 154-169. doi: 10.1207/s15327752jpa8502_08

Ciarrochi, J., Chan, A. Y. C., \& Bajgar, J. (2001). Measuring emotional intelligence in adolescents. Personality and Individual Differences, 31(7), 1105-1119. doi: 10.1016/S0191-8869(00)00207-5

Ciarrochi, J. V, Chan, A. Y. ., \& Caputi, P. (2000). A critical evaluation of the emotional intelligence construct. Personality and Individual Differences, 28(3), 539-561. doi: 10.1016/S0191-8869(99)00119-1

Cortina, J. M. (1993). What is Coefficient Alpha? An examination of theory and application. Journal of Applied Psychology, 78(1), 98-104.

Costa, A. C. F., \& Faria, L. M. S. (2014). Avaliação da inteligência emocional: a relação entre medidas de desempenho e de autorrelato. Psicologia: Teoria e Pesquisa, 30(3), 339-346. doi: 10.1590/s0102-37722014000300011

Dawda, D., \& Hart, S. D. (2000). Assessing emotional intelligence: Reliability and validity of the Bar-On Emotional Quotient Inventory (EQ-i) in university students. Personality and Individual Differences, 28(4), 797-812. doi: 10.1016/S0191-8869(99)00139-7

De Haro, J.-M., \& Castejón, J.-L. (2014). Inteligencia emocional percibida, inteligencia general y éxito profesional en el inicio de la carrera: validez predictiva e incremental. Anales de Psicología, 30(2), 490-498. doi: 10.6018/analesps.30.2.154621

Extremera, N., Fernández-Berrocal, P., Ruiz-Aranda, D., \& Cabello, R. (2006). Inteligencia emocional, estilos de respuesta e depressión. Ansiedad y Estrés, 12(2), 191-205.

Faria, L., Santos, N. L., Takšić, V., Räty, H., Molander, B., Holmström, S., ... Toyota, H. (2006). Cross-cultural validation of the Emotional Skills and Competence Questionnaire (ESCQ). Psicologia, XX(2), 95-127.

Fernández-Berrocal, P., \& Extremera, N. (2006). Special issue on emotional intelligence: An overview. Psicothema, 18(SUPPL.1), 1-6.

Field, A. (2013). Discovering statistics using SPSS (4th ed.). London, UK: Sage. doi: 10.1234/12345678

Ford, J. K., MacCallum, R. C., \& Tait, M. (1986). The Application of Exploratory Factor-Analysis in Applied Psychology - A Critical-Review and Analysis. Personnel Psychology, 39(2), 291-314. doi: 10.1111/j.1744-6570.1986.tb00583.x

Fragoso-Luzuriaga, R. (2015). Inteligencia emocional y competencias emocionales en educación superior, ¿un mismo concepto? Revista Iberoamericana de Educacion Superior, 6(16), 110-125. doi: 10.1016/j.rides.2015.02.001

Fukuda, E., Saklofske, D. H., Tamaoka, K., Fung, T. S., Miyaoka, Y., \& Kiyama, S. (2011). Factor structure of Japanese versions of two Emotional Intelligence Scales. International Journal of Testing, 11(1), 71-92. doi: 10.1080/15305058.2010.516379

Galinha, I. C., Pereira, C. R., \& Esteves, F. (2014). Versão reduzida da escala portuguesa de afeto positivo e negativo - PANAS-VRP: Análise fatorial confirmatória e invariância temporal. Revista Psicologia, 28(1), 53-65.

García-Coll, V., Graupera-Sanz, J.-L., Ruiz-Pérez, L.-M., \& Palomo-Nieto, M. (2013). Inteligencia Emocional en el Deporte : Validación española del Schutte Self Report Inventory ( SSRI ) en deportistas españoles. Cuadernos de Psicologia Del Deporte, 13(1), 25-36.

George, D., \& Mallery, P. (2003). SPSS for Windows step by step: A simple guide and reference. 11.0 update (4th ed.). Boston: Allyn \& Bacon.

Gignac, G. E., Palmer, B. R., Manocha, R., \& Stough, C. (2005). An examination of the factor structure of the schutte self-report emotional intelligence (SSREI) scale via confirmatory factor analysis. Personality and Individual Differences, 39(6), 1029-1042. -doi: 10.1016/j.paid.2005.03.014

Gjersing, L., Caplehorn, J. R., \& Clausen, T. (2010). Cross-cultural adaptation of research instruments: language, setting, time and statistical considerations. BMC Medical Research Methodology, 10(1), 13. doi: 10.1186/1471-2288-10-13

Goleman, D. (1995). Emotional intelligence. New York: Bantam.

Goleman, D. (1998). Working with Emotional Intelligence. New York: Bantam Book.

Jonker, C. S., \& Vosloo, C. (2008). The psychometric properties of the Schutte Emotional Intelligence Scale. SA Journal of Industrial Psychology, 34(2), 21-30. doi: 10.4102/sajip.v34i2.689

Keele, S. M., \& Bell, R. C. (2008). The factorial validity of emotional intelligence: An unresolved issue. Personality and Individual Differences, 44(2), 487-500. doi: 10.1016/j.paid.2007.09.013

Kun, B., Balazs, H., Kapitany, M., Urban, R., \& Demetrovics, Z. (2010). Confirmation of the three-factor model of the Assessing Emotions Scale (AES): verification of the theoretical starting point. Behavior Research Methods, 42(2), 596-606. doi: 10.3758/BRM.42.2.596

Lane, A. M., Meyer, B. B., Devonport, T. J., Davies, K. a, Thelwell, R., Gill, G. S., ... Weston, N. (2009). Validity of the emotional intelligence scale for use in sport. Journal of Sports Science \& Medicine, 8(2), 289-295. 
Leech, N. L., Barrett, K. C., \& Morgan, G. A. (2015). IBM SPSS for Intermediate Statistics: Use and Interpretation (5th ed.). New York, NY: Routledge.

Mayer, J. D., Caruso, D. R., \& Salovey, P. (2000a). Emotional intelligence meets traditional standards for an intelligence. Intelligence, 27(4), 267-298.

Mayer, J. D., Caruso, D. R., \& Salovey, P. (2000b). Selecting a measure of Emotional Intelligence. In R. Bar-On \& J. D. A. Parker (Eds.), The Handbook of Emotional Intelligence (pp. 320-342). San Francisco, CA: Jossey-Bass.

Mayer, J. D., Roberts, R. D., \& Barsade, S. G. (2008). Human Abilities: Emotional Intelligence. Annual Review of Psychology, 59(1), 507-536. doi: 10.1146/annurev.psych.59.103006.093646

Mayer, J. D., Salovey, P., \& Caruso, D. R. (2004). Emotional Intelligence: theory, findings, and implications. Psychological Inquiry, 15(3), 197215.

Mayer, J. D., Salovey, P., Caruso, D. R., \& Sitarenios, G. (2003). Measuring emotional intelligence with the MSCEIT V2.0. Emotion, 3(1), 97-105. doi: 10.1037/1528-3542.3.1.97

Maroco, J., \& Garcia-Marques, T. (2006). Qual a fiabilidade do alfa de Cronbach? Questões antigas e soluções modernas. Laboratório de Psicologia, 4(1), 65-90.

Nunnaly, J. (1978). Psychometric theory. New York: Mc Graw-Hill.

Ng, K.-M., Chuang Wang, Kim, D.-H., \& Bodenhorn, N. (2010). Factor structure analysis of the Schutte Self-Report Emotional Intelligence Scale on international students. Educational and Psychological Measurement, 70(4), 695-709. doi: 10.1177/0013164409355691

Ogińska-Bulik, N. (2005). Emotional intelligence in the workplace: Exploring its effects on occupational stress and health outcomes in human service workers. International Journal of Occupational Medicine and Environmental Health, 18(2), 167-175.

Omar, A., Salessi, S., Urteaga, F., Diego, J., \& Vaamonde. (2014). Validación transcultural de la Escala de Inteligencia Emocional de Schutte. Revista Diversitas - Perspectivas En Psicología, 10(2), 261-274.

Patil, V. H., Singh, S. N., Mishra, S., \& Todd Donavan, D. (2008). Efficient theory development and factor retention criteria: Abandon the 'eigenvalue greater than one' criterion. Journal of Business Research, 61(2), 162-170. doi: /10.1016/j.jbusres.2007.05.008

Petrides, K., \& Furnham, A. (2000). On the dimensional structure of emotional intelligence. Personality and Individual Differences, 29(2), 313320. doi: 10.1016/S0191-8869(99)00195-6

Qualter, P., Ireland, J., \& Gardner, K. (2010). Exploratory and confirmatory factor analysis of the Schutte Self-Report Emotional Intelligence Scale (SSREI) in a sample of male offenders. The British Journal of Forensic Practice, 12(2), 43-51. doi: 10.5042/bjfp.2010.0185

Queroz, N. C., \& Neri, A. L. (2005). Bem-estar psicológico e inteligência emocional entre homens e mulheres na meia-idade e na velhice. Psicologia: Reflexão e Crítica, 18(2), 292-299. doi: 10.1590/S0102-79722005000200018

Ramsey, S. R., Thompson, K. L., McKenzie, M., \& Rosenbaum, A. (2016). Psychological research in the internet age: The quality of webbased data. Computers in Human Behavior, 58, 354-360. doi: 10.1016/j.chb.2015.12.049

Regner, E. (2008). Validez convergente y discriminante del inventario de cociente emocional. Interdisciplinaria, 25(1), 29-51.

Rego, A., \& Fernandes, C. (2005). Inteligência emocional: Contributos adicionais para a validação de um instrumento de medida. Psicologia, 19(1/2), 139. doi: 10.17575/rpsicol.v19i1/2.401

Rodrigues, N., Rebelo, T., \& Coelho, J. V. (2011). Adaptação da Escala de Inteligência Emocional de Wong e Law (WLEIS) e análise da sua estrutura factorial e fiabilidade numa amostra portuguesa. Psychologica, 55, 189-207.

Saklofske, D. H., Austin, E. J., Mastoras, S. M., Beaton, L., \& Osborne, S. E. (2012). Relationships of personality, affect, emotional intelligence and coping with student stress and academic success: Different patterns of association for stress and success. Learning and Individual Differences, 22(2), 251-257. doi: 10.1016/j.lindif.2011.02.010

Saklofske, D. H., Austin, E. J., \& Minski, P. S. (2003). Factor structure and validity of a trait emotional intelligence measure. Personality and Individual Differences, 34(4), 707-721. doi: 10.1016/S0191-8869(02)00056-9

Satuf, C. V. V., Monteiro, S. J. F., Pereira, H., Esgalhado, G., Afonso, R. M., \& Loureiro, M. (2018). A influência da satisfação laboral no bem-estar subjetivo: uma perspectiva geracional. Psicologia: Teoria e Pesquisa, 34(1). doi: 10.1590/0102.3772e3451

Salovey, P., \& Mayer, J. D. (1990). Emotional Intelligence. Imagination, Cognition and Personality, 9(3), 185-211. doi: 10.2190/DUGG-P24E$52 \mathrm{WK}-6 \mathrm{CDG}$

Salovey, P., Mayer, J. D., Goldman, S. L., Turvey, C., \& Palfai, T. P. (1995). Emotional attention, clarity, and repair: exploring emotional intelligence using the Trait Meta-Mood Scale. In J. W. Pennebaker (Ed.), Emotion, disclosure, \& health. Washington, DC: American Psychological Association. doi: 10.1037/10182-000

Schutte, N. S., Malouff, J. M., \& Bhullar, N. (2009). The Assessing Emotions Scale. In C. Stough, D. Saklofske, \& J. Parker (Eds.), The Assessment of Emotional Intelligence (pp. 119-135). New York, NY: Springer. doi: 10.1017/CBO9781107415324.004

Schutte, N. S., Malouff, J. M., Bobik, C., Coston, T. D., Greeson, C., Jedlicka, C., ... Wendorf, G. (2001). Emotional Intelligence and Interpersonal Relations. The Journal of Social Psychology, 141(4), 523-536. doi: 10.1080/00224540109600569

Schutte, N. S., Malouff, J. M., Hall, L. E., Haggerty, D. J., Cooper, J. T., Golden, C. J., \& Dornheim, L. (1998). Development and validation of a measure of emotional intelligence. Personality and Individual Differences, 25(2), 167-177. doi: 10.1016/S0191-8869(98)00001-4

Schutte, N. S., Malouff, J. M., Simunek, M., McKenley, J., \& Hollander, S. (2002). Characteristic emotional intelligence and emotional well-being. Cognition and Emotion, 16(6), 769-785. doi: 10.1080/02699930143000482

Sjoberg, L. (2001). Emotional Intelligence: A Psychometric Analysis. European Psychologist, 6(2), 79-95. doi: 10.1027//1016-9040.6.2.79

Sjöberg, L., \& Engelberg, E. (2004). Measuring and Validating Emotional Intelligence as Performance or Self-Report (No. 2004:3). Stockholm.

Stevens, J. P. (2009). Applied multivariate statistics for the social sciences. Group (5th ed.). New York, NY: Routledge.

Stys, Y., \& Brown, S. (2004). A review of the emotional intelligence literature and implications for corrections. Research Branch Correctional Service of Canada.

Toledo Júnior, A., Duca, J. G. M., \& Coury, M. I. F. (2018). Tradução e adaptação transcultural da versão brasileira do Schutte Self-Report Emotional Intelligence Test. Revista Brasileira de Educação Médica, 42(4), 109-114. doi: 10.1590/1981-52712015v42n4rb20180102

Trujillo Flores, M. M., \& Rivas Tovar, L. A. (2005). Orígenes, evolución y modelos de inteligencia emocional. INNOVAR. Revista de Ciencias Administrativas y Sociales, 15(25), 9-24. 
Vaus, D. A. de. (2014). Surveys in Social Research (6th ed.). Oxon, UK: Routledge. doi: 10.2307/2071069

Vicente, L. C. M. (2014). Validação da Escala de Inteligência Emocional de Schutte: Impacto da intervenção por mensagens SMS na Inteligência Emocional e Inteligência Espiritual em estudantes de Psicologia (Dissertação de Mestrado em Psicologia). Covilhã, Portugal, Dep. Psicologia, Universidade Beira Interior.

Woyciekoski, C., \& Hutz, C. S. (2009). Inteligência emocional: Teoria, pesquisa, medida, aplicações e controvérsias. Psicologia: Reflexão e Crítica, 22(1), 1-11. doi: 10.1590/S0102-79722009000100002

\section{Sobre os autores}

Cibele Satuf. MSc in Work and Organizational Psychology. PhD Candidate, FAPEMIG research fellow. Department of Sociology, Federal University of Minas Gerais.

Samuel Monteiro. PhD in Psychology. Research Center in Business Sciences (NECE-UBI) and Department of Psychology and Education, Faculty of Social and Human Sciences, University of Beira Interior, Assistant Professor.

Graça Esgalhado. PhD in Psychology. Department of Psychology and Education, Faculty of Social and Human Sciences, University of Beira Interior, Assistant Professor.

Henrique Pereira. PhD in Applied Psychology. Department of Psychology and Education, Faculty of Social and Human Sciences, University of Beira Interior, Assistant Professor with "Agregação".

Rosa Marina Afonso. PhD in Psychology. Department of Psychology and Education, Faculty of Social and Human Sciences, University of Beira Interior, Assistant Professor.

Manuel Loureiro. PhD in Psychology. Department of Psychology and Education, Faculty of Social and Human Sciences, University of Beira Interior, Full Professor. Research Center in Sports Sciences, Health Sciences and Human Development, CIDESD.

Maria Miguel Barbosa. MSc in Clinical and Health Psychology. Department of Psychology and Education, Faculty of Social and Human Sciences, University of Beira Interior. 